\title{
Determinant of the quality of the national financial audit report: study at National Auditor Board Jambi Province
}

\author{
Yudi*; Sri Rahayu \\ Faculty of Economics and Business, Universitas Jambi, Indonesia \\ *To whom correspondence should be addressed.Email: yudi.telanai@ gmail.com.
}

\begin{abstract}
This study aimed to examine the effect of training, experiences, gender, age and educational background possessed by the auditor on the quality of State Financial Audit results. This research used secondary data provided by Audit Board of the Republic of Indonesia Representative of Jambi Province in the form of 2016 and 2017 staffing data and Audit Reports. Multiple linear regression analysis was used for the analysis method. The study results found that the quality of the state financial audit was affected by experiences. However, the study failed to find the influences of age, education, and gender on the quality of state financial audit results. It provides empirical evidence that the auditor's ability to find and reveal findings has been influenced by experiences of the auditor.
\end{abstract}

Keywords: State financial audit, Training, Experiences, Gender, Education

JEL Classification: M42, M48

\section{INTRODUCTION}

Three packages of State Finance Laws, namely Law No. 17 Year 2003 on State Finance, Law No. 1 Year 2004 on State Treasury, and Law No. 15 Year 2004 on Examination of Management and Responsibility of State Finance, reinforced the position of the Audit Board as the only institution with the authority to carry out audits on the management and responsibility of state finance.

As a result, the role of Audit Board becomes more important and it can be seen from the strategic role of the Audit Board in resolving corruption cases as the concern of many parties. An Audit Board's investigative audit in 2009 revealed a state loss of 7.4 trillion in the case of Century Bank. Long before the case of Century Bank, an audit conducted by the Audit Board in 1999 even succeed in revealing the case of Bank Indonesia Liquidity Support/Bantuan Likuiditas Bank Indonesia (BLBI) which was detrimental to state finances amounting to 138.4 trillion (Pandoman, 2014).

In line with those successes, the audit reports of the Audit Board also have an important role in settling corruption cases. They are widely used as an initial source of information by law enforcement officials (Indonesian National Police, Corruption Eradication Commission/Komisi Pemberantasan Korupsi (KPK), and Public Prosecution Service of the Republic of Indonesia) in investigating corruption cases. Some cases that relied on the audit report of Audit Board as their initial source of information were case of official travel at Culture and Tourism Office of Jambi Province (Tempo, 2009) and case of misuse of grant funds of National Sports Committee of Indonesia (Komite 
Olahraga Nasional Indonesia/KONI) of Bangka Regency, West Bangka, where the chairman was under arrest (Tribun Jateng, 2017).

The success of the Audit Board in revealing indications of corruption is inseparable from the auditor's ability to find and disclose as many as possible errors and fraud committed by the auditee in their audit reports. The role of detecting fraud is in fact the auditors' historical role (Rukmawati and Chariri, 2011; Irianto, 2003). Auditors are required to be able to reveal more fraud committed by the auditee.

Failure by auditor to disclose fraud will result in potential lawsuits from the public as the biggest stakeholders of the Audit Board's audit reports. Irianto (2003) stated that the huge number of lawsuits from users of financial information to auditors is due to the expectation gap related to the auditor's responsibility to detect fraud. Financial information users expect auditors to be able to detect and report fraud to the public, while auditors work based on audit standards which are sometimes not in line with public expectations.

Public believes that, in carrying out each task, the Audit Board must be able to disclose any fraud and disclose it in audit reports. On the other hand, auditors of Audit Board assume that their responsibility is to carry out auditing that refer to the SPKN (Standar Pemeriksaan Keuangan Negara)/State Financial Audit Standards. So, if they had conducted in accordance with SPKN, they assumed that their responsibilities were fulfilled regardless of whether or not there were findings related to state losses. Based on the explanation, it can be concluded that a good quality audit report is an audit report that is an accordance with the expectations of public, namely reports that disclose as many findings as possible related to errors and fraud committed by the auditee.

The existence of lawsuits affecting Audit Board auditors, however, raised public doubts. Some cases of lawsuits involvingauditors are the case of the KPK doing a sting operation or Operasi Tangkap Tangan (OTT) on Friday, May 26, 2017 at two locations, namely at Audit Board of Republic of Indonesia office and Ministry of Village, Development of Disadvantaged Regions and Transmigration/Kementerian Desa, Pembangunan Daerah Tertinggal dan Transmigrasi (Kemendes PDTT) office related to opinions to Kemendes PDTT (Detiknews, 2017), and other bribery cases that befell the West Java representative auditor relating to the provision of unqualified opinion for Bekasi City (tirto.id, 2017). The existence of potential lawsuits encourages auditors to be more careful in conducting audits and attempt to reveal errors and fraud committed by the auditee as much as possible.

Semester Audit Results II Year 2016 of Audit Board of Republic of Indonesia about the quality of Report on local government finances/Laporan Keuangan Pemerintah Daerah (LKPD) of provincial/regency/city governments in Jambi Province provided an overview of opinions of LKPD in 2012-2016 in Table 1.

The auditor's ability to find errors and fraud besides relied on his competence is also influenced by the auditee. Auditors will tend to find more errors and cheat from new auditee where their financial management is not as good as the auditee that has been established for quite a long time with good financial management. Jambi Province is a long-standing entity. The province consists of 12 entities, namely one province, two cities and nine regencies. The subjects of the research are auditors at Audit Board representative of Jambi Province office. Research on the quality of the results of state financial reports using the number of audit findings as a proxy for the quality of audit results has not been done much. The research conducted by Setyaningrum (2012) used the findings value as a proxy for the quality of Audit Board's AR, and also the study used independent variables in the form of auditor and auditee characteristics, and control variables in the form of the age of local government and the quality of previous year's audit reports. 
Table 1. Opinions of LKPD Year 2012-2016 of provincial/regency/city governments in Jambi Province

\begin{tabular}{lccccc}
\hline \multirow{2}{*}{ Regency/City/Province } & \multicolumn{5}{c}{ Year } \\
\cline { 2 - 6 } & $\mathbf{2 0 1 2}$ & $\mathbf{2 0 1 3}$ & $\mathbf{2 0 1 4}$ & $\mathbf{2 0 1 5}$ & $\mathbf{2 0 1 6}$ \\
\hline Batanghari Regency & WTP-PDP & WTP-PDP & WDP & WTP & WTP \\
Bungo Regency & WDP & WDP & WDP & WDP & WDP \\
Kerinci Regency & WDP & WDP & WTP-PDP & WTP & WTP \\
Merangin Regency & WDP & WDP & WDP & WDP & WTP \\
Muaro Jambi Regency & WTP & WTP & WDP & WDP & WTP \\
Sarolangun Regency & WDP & WDP & WDP & WDP & WTP \\
Tanjung Jabung Barat Regency & WDP & WDP & WDP & TMP & WTP \\
Tanjung Jabung Timur Regency & WTP-WDP & WTP-WDP & WDP & WDP & WDP \\
Tebo Regency & WDP & WDP & WDP & WTP & WTP \\
Jambi City & WDP & WDP & WDP & TMP & WTP \\
Sungai Penuh City & WTP & WDP & WTP-PDP & WTP & WTP \\
Jambi Province & WTP-PDP & WTP-PDP & WTP-PDP & WDP & WTP \\
\hline
\end{tabular}

Source: Semester Audit Results Summary (IHPS) I Year 2017 of Audit Board of Republic of Indonesia

The characteristics of auditors consist of educational backgrounds that are measured based on the education level of the team leader, professional skills measured based on the years of service of the team leader, and continuing education measured by the number of trainings attended by the team leader. The auditee characteristics consist of the size of the local government as measured by the total assets, the complexity of local government as a dummy variable, previous year's audit quality measured by the value of previous year's findings divided by previous year's asset, as well as the age of the local government since the issuance of legislation establishing the local government.

The research conducted by Setyaningrum (2012) found that auditor characteristics and auditee characteristics simultaneously affected audit quality but partially the characteristics of auditors consisting of educational backgrounds, professional skills, and continuing professional education did not significantly influence audit quality, whereas for auditee characteristics, only the size of local government was proven to negatively affect audit quality.

Based on the explanation above, the author is interested on conducting research on determinants of the quality of the national financial audit report. This study took cases at the National Auditor Board Jambi Province.

\section{METHODS}

Primary data for this study are from Audit Board of the Republic of Indonesia Representative of Jambi Province. The population in this study is all the auditors in Audit Board of the Republic of Indonesia Representative of Jambi Province, as many as 51 people. The entire population is determined as a sample of study (saturation sampling)

Data were analyzed descriptively to describe and summarize the important things from the data. To analyze the determinants of the quality of the national financial audit reports, the OLS regression model is used with the following equation:

$\mathrm{Y}=\beta_{0}+\beta_{1} \mathrm{X}_{1}+\beta_{2} \mathrm{X}_{2}+\beta_{3} \mathrm{X}_{3}+\beta_{4} \mathrm{X}_{4}+\varepsilon_{\mathrm{i}}$

where:

$\mathrm{Y}=$ quality of report

$\mathrm{X} 1=$ age

$\mathrm{X} 2=$ level of education

$\mathrm{X} 3$ = gender

$\mathrm{X} 4=$ experiences

The definition and the measurement of varibles as given as Table 2 
Table 2. Characteristics of respondents

\begin{tabular}{cll}
\hline $\begin{array}{c}\text { Code of } \\
\text { variable }\end{array}$ & $\begin{array}{l}\text { Name of } \\
\text { variable }\end{array}$ & Measurement \\
\hline Y & Quality of audits & $\begin{array}{l}\text { Number of audit findings by auditor over the past two years } \\
(2016-2017)\end{array}$ \\
X1 & Age & $\begin{array}{l}\text { Age of auditor at the time of study (in years) } \\
\text { Latest level of formal education of auditor, categorized and } \\
\text { measured by 1=Diploma 3 (D3), 2=Diploma 4 (D4), 3=Strata } \\
1(\mathrm{~S} 1), \text { and 4=Strata 2 (S2) }\end{array}$ \\
X2 & Education & The gender of auditor, $0=$ female and 1=male \\
Length of years of service as auditor (in years)
\end{tabular}

\section{RESULTS AND DISCUSSION}

\section{Characteristics of auditors}

The characteristics of the active auditors with examiner-functional status at the Audit Board Representative of Jambi Province are given in Table 3. The proportion of auditors at Audit Board representative of Jambi Province based on gender was relatively balanced. Of the total, $54.9 \%$ were men and $45.1 \%$ were women. Based on the age, it showed that most of auditors (50.98\%) were between 31-40 years old.

Table 3. Characteristics of respondents

\begin{tabular}{|c|c|c|}
\hline Characteristics & Frequency & Percentage (\%) \\
\hline \multicolumn{3}{|l|}{ Gender } \\
\hline Male & 28 & 54.9 \\
\hline Female & 23 & 45.1 \\
\hline Total & 51 & 100.00 \\
\hline \multicolumn{3}{|l|}{ Age } \\
\hline $20-30$ & 15 & 29.41 \\
\hline $31-40$ & 26 & 50.98 \\
\hline $41-50$ & 9 & 17.65 \\
\hline $51-60$ & 1 & 1.96 \\
\hline Total & 51 & 100.00 \\
\hline \multicolumn{3}{|l|}{ Years of service } \\
\hline $11-20$ & 48 & 94.12 \\
\hline $21-30$ & 2 & 3.92 \\
\hline $31-40$ & 1 & 1.96 \\
\hline Total & 51 & 100.00 \\
\hline \multicolumn{3}{|l|}{ Level of education } \\
\hline Diploma 3 degrees (D-3) & 4 & 7.84 \\
\hline Diploma 4 degrees (D-4) & 2 & 3.92 \\
\hline Bachelor degrees (Strata-1) & 35 & 68.63 \\
\hline Master degrees (Strata-2) & 10 & 19.61 \\
\hline Total & 51 & 100.00 \\
\hline \multicolumn{3}{|l|}{ Position } \\
\hline Middle auditor & 2 & 3.92 \\
\hline Junior auditor & 20 & 39.22 \\
\hline First auditor & 29 & 56.86 \\
\hline Total & 51 & 100.00 \\
\hline
\end{tabular}


Based on work experience, $94.12 \%$ of the total auditor had been in their $11^{\text {th }}$ to $20^{\text {th }}$ year of service, $3.92 \%$ were in their $21^{\text {st }}$ to $30^{\text {th }}$ year of service, and $1.96 \%$ was in between his/her $31^{\text {st }}$ and $40^{\text {th }}$ year of service.

Based on the level of education, most of auditors $(68,63 \%)$ had S1 as their highest level of education. Furthermore, 19.61\% had a master's degree (S2), 7.84\% had D3 degree, and $3.92 \%$ had D4 degree. Education major of auditors based on data of staffs from Audit Board, as follows: 56.45\% were majoring in Accounting, $11.29 \%$ were majoring in Law, 9.68\% were majoring in Engineering, 9.68\% auditors were majoring in Management $(9.68 \%)$ and others were majoring in Public Policy, Taxation, Administration, Computers, and even Agriculture as many as $12.90 \%$.

Most of active auditors with examiner-functional status in Audit Board representative of Jambi Province were first auditor/Pemeriksa Pertama of $56.86 \%$ auditors, $39.22 \%$ auditors are junior auditor/Pemeriksa Muda, and 3.92\% auditors are middle auditor/Pemeriksa Madya.

\section{The quality of the audit report}

The quality of the audit report was measured by the number of audit findings over the past two years. During 2016, Audit Board representative of Jambi Province generated 17 audit reports with a total of 83 findings. The report was based on the results of the audits of the government of Jambi Province and eight regencies/cities in Jambi Province.

During 2017, Audit Board representative of Jambi Province generated 12 reports with a total of 115 findings. The report was based on the results of audits of the government of Jambi Province and nine regencies/cities in Jambi Province, and also PDAM Tirta Mayang Jambi City.

Based on the results, it shows that there was a decrease in the number of agencies that were audited and the audit reports between 2016 and 2017. However, during those two years, there was an increase of audit findings. List of entities and reports on audit results are given in detail in Appendix 1 and Appendix 2.

\section{Determinant of the quality of the national financial audit report}

Model estimation of determinants of the quality of the national financial audit reports are given in Table 4 and 5. Table 4 shows the results of the ANOVA with a calculated $\mathrm{F}$ value of 56.89. It can be concluded that the regression model can be used to predict audit quality. Also, it can be said that all variables (experience, gender, age, and education) influence the quality of the audit of Audit Board representative of Jambi Province.

Table 4. ANOVA and coefficient of determination

\begin{tabular}{lccccc}
\hline \multicolumn{1}{c}{ Model } & Sum of Squares & df & Mean Square & F & Sig. \\
\hline Regression & 37.124 & 4 & 9.281 & 56.896 & $.000^{\mathrm{b}}$ \\
Residual & 7.504 & 46 & .163 & & \\
Total & 44.627 & 50 & & \\
\hline $\mathrm{R} \quad=0.912$ & & Adjusted R Square $=0.817$ \\
$\mathrm{R}$ Square $=0.832$ & & Std. Error of the Estimate $=0.40388$ & \\
\hline
\end{tabular}

The coefficient of determination basically measures how far the ability of the model to explain the variation of dependent variables (Gozali, 2011). It can be seen that the adjusted $R$ square value is 0.832 , which means that $83.2 \%$ of the variation in audit quality that can be explained by independent variables, namely age, education, gender and experience, whereas $16.8 \%$ of the variation is explained by other reasons outside the research model. The Standard Error Estimate (SEE) is $40.3 \%$, the smaller the SEE value will make the regression model more precise in predicting the dependent variable. 
Partially, the result seen in Table 5. Of the four independent variables that are included in the regression model, experiences have influence, whereas education, gender, and age have no influence.

Table 5. Regression estimation result

\begin{tabular}{lcccccc}
\hline \multirow{2}{*}{ Model } & \multicolumn{2}{c}{ Unstandardized Coefficients } & Standardized Coefficients & \multirow{2}{*}{ t } & \multirow{2}{*}{ Sig. } \\
\cline { 2 - 4 } & $\mathbf{B}$ & Std. Error & Beta & & 2,691 &, 010 \\
\hline Constant) & 1,402 &, 521 &, 149 & & 1,070 &, 290 \\
Age &, 022 &, 020 &,- 047 &,- 726 &, 472 \\
Education &,- 059 &, 081 &,- 099 & $-1,623$ &, 111 \\
Gender &,- 187 &, 115 &, 792 & 5,740 &, 000 \\
Experiences &, 126 &, 022 & &
\end{tabular}

Quality of audit can be achieved by fulfilling the competences of auditors realized through age and experience in conducting audits. Educated auditors and gender have an influence in generating audit that are needed and have an impact on improving audit quality.

\section{Effect of age on audit quality}

Age of auditor does not affect the quality of the audit reports. The results of this study are inconsistent with the research conducted by Widiarta (2013), who found that age affects the quality of audit reports. Widiarta (2013) explained that age is a factor in individual level that influences the professionalism of auditors. An auditor of the Audit Board (BPK) is required to be always professional when carrying out his/her duties. This is in line with the State Financial Audit Standards (SPKN) which obliges auditors to maintain their integrity, objectivity, independence, and professionalism in conducting audit. Ideally, their professionalism also improves as the age of a person increases. All auditors, both junior auditors and senior auditors, are bound by this professionalism.

On the other hand, professionalism is often associated with auditor compliance with audit standards in carrying out audits. The auditor's ability to disclose a finding is not only obtained through its compliance with audit standards. Moreover, the ability to disclose findings depends more on how the auditor can think creatively and develop alternative audit procedures to be able to detect possible fraud committed by the auditee.

Furthermore, Wirosari and Fanani (2017) explained that the older the auditor, the more conservative in obtaining evidence to reduce risk to a lower level, in other words, the procedure and sampling are more to prove the truth of the financial statements prepared by management so the degree of confidence in the opinion issued is greater.

\section{Effect of education on audit quality}

Educational background of auditor does not affect the quality of the audit reports. The results of this study in line with the research of Setyaningum (2012) which found that the level of education or educational background did not influence the quality of the audit reports. In contrast to the findings of this study, the auditor's educational background influences the auditor's ability to find and disclose errors and fraud.

Johnie (1993) explained that education is one of the competency requirements to fulfill the basic qualifications as an auditor, which is also the main consideration in this study for linking the influence of education on risk behavior in relation to audit risk on the entity's financial statements. Education should directly or indirectly influence the mindset and tendency of auditors in dealing with audit risk. According to the researcher, there are differences in the ability to find and disclose findings between auditors with level of education of Diploma 3, Diploma 4, Bachelor (Strata 1) and Strata 2.

Based on an interview with the Head of the Audit Board Representative of Jambi 
Province, Mr. Parna, one of the requirements of an auditor these days is having a minimum of Bachelor's degree. However, employees who are accepted to work at Audit Board must attend basic trainings as an auditor. The basic trainings are divided into two, namely education for expert auditor for undergraduates and education for skilled auditor for diploma 3 graduates. Both trainings are intended to conform the auditor's knowledge about the concept of audit learned in college to the actual audit practices to be conducted when they works at Audit Board. By having these two basic trainings, both auditors have the same knowledge regarding audit practices.

\section{Effects of gender on audit quality}

Gender have no influences the quality of audit reports. The results of this study are not in line with the research of Sabrina and Januarti (2012) which concluded that gender affects the audit opinions. The characteristics of female and male auditors lied in their ability to process information. Meyers and Levy (1989) in the study of Sabrina and Januarti (2011) explained that the development of a theoretical framework called the selectivity hypothesis assumed men will be better than women in making decisions or judgments. Decisions in this case will affect the opinions that will be given.

If it is associated with the time of completion of tasks, men will be much faster in carrying out simple tasks because the heuristic processing strategies used by men can be used more quickly when compared to the elaborative processing strategies used by women. Women tend to be more efficient when facing complex tasks because women are more trained in using elaborative strategies than men who rarely use these strategies.

In addition, Riley \& Chow (1992) and Jayathilake (2013) found that the behavior of avoiding risk would be lower in men compared to women. Furthermore, men have more intention in confronting something challenging or sensation making so that men will consequently tend to like risks, which will be inversely proportional to women that avoid risks more than man.

\section{Effects of experience on audit quality}

Experience have affected the quality of audit reports. The results of this study in line with Sukriyah and Inapty research (2009), but are not in line with the results of Setyaningrum's research (2012). Audit experience is not only based on year of service, knowledge regarding audit can also be obtained during an audit task. It includes on how the auditor communicates with the auditee, how an auditor plans alternative audit procedures to find fraud and errors, and how the auditor performs audit procedures effectively and efficiently, and so on. Knowledge of these matters will only be obtained by the auditor through a series of audit assignments. Through its audit assignments, an auditor can learn from senior auditors on how to find errors and fraud.

Once novice auditors find out how senior auditors find errors or frauds through certain audit procedures, they could use similar audit procedures on other audit entities and attempt to find the same errors or frauds. So, the more audit tasks done by an auditor, the more knowledge the auditor obtained about how errors and fraud occur and which audit procedures can be applied to detect such errors and fraud. Broader knowledge will improve the auditor's ability to find and disclose errors and fraud in his findings.

\section{CONCLUSIONS AND RECOMMENDATIONS}

\section{Conclusions}

Based on the results of this study, it can be concluded that the factor that influence the quality of the results of state financial audit is experiences. The results of this study did not succeed in finding the influence of age, education, and gender on the quality of the state financial audit reports. The most uninfluential factor in the quality of the state 
financial audit reports is education, and then it is followed by age. This provides empirical evidence that the auditor's ability to find and reveal findings is influenced by experiences of the auditor.

\section{Recommendations}

First, further researches are expected to use other variables such as auditee characteristics (such as government size) and independence to be more comprehensive so that the results of the study are able to generalize the factors that influence the quality of the audit reports of Audit Board of the Republic of Indonesia. Measurement of educational background as a variable in this study used ordinal scale. Second, we recommend that interval scales and ratio scales in future studies can be considered for different research results. Third, the object of further research is better carried out for all active auditors with examiner-functional status who work in all representative offices in Indonesia using cross section data, so that research data is more varied and the results of adjusted $\mathrm{R}$ can be higher.

\section{ACKNOWLEDGMENT}

We are very grateful to Postgraduate Program in Accounting, Universitas Jambi for funding this research through the DIPA PNBP for Group Research for FY 2018.

\section{REFERENCES}

Ghozali, I. (2011). Aplikasi Analisis Multivariate dengan Program IBM SPSS. Semarang: Badan Penerbitan Universitas Diponegoro.

Irianto, G., (2003), Skandal Korporasi dan Akuntan. Lintasan Ekonomi. XX(2), 104-114. Sabrina \& Januarti, I., (2012), Pengaruh Pengalaman, Keahlian, Situasi Audit, Etika, dan Gender terhadap Ketepatan Pemberian Opini Audit melalui Skeptisme profesional Auditor (Studi Kasus pada KAP Big Four di Jakarta). Proceeding. Simposium Nasional Akuntansi XV, Banjarmasin.

Jayathilake, P.M.B., (2013), Gender Effects on Risk Perception and Risk Behavior of Entrepreneurs at SME'S in Sri Lanka. Asia Pasific Journal of Marketing \& Management Review. 2 (2), 1 - 11

Johnie, P., (1993), Formal Education: A Paradigm of Human Resource Development. The International Journal of Educational Management. 7 (5), 4-8.

Pandoman. (2014) Penyelesaian Utang BLBI dalam Kajian Hukum Responsif dan Represif. Yogyakarta: Penerbit Jawara.

Riley, W.B., \& Chow, K. V. (1992). Asset Allocation and Individual Risk Aversion. Financial Analysts Journal, 48 (6), 32-37.

Rukmawati, A.D., \& Chariri, A. (2011). Persepsi Manajer dan Auditor Eksternal Mengenai Efektivitas Metode Pendeteksian dan Pencegahan Tindakan Kecurangan Keuangan. Dissertation. Universitas Diponegoro.

Setyaningrum, D. (2012). Analisis Faktor-Faktor yang Mempengaruhi Kualitas Audit BPK RI. Paper. Simposium Nasional Akuntansi (SNA) XV. IAI. Banjarmasin.

Sukriyah, I., \& Inapty, B. A (2009). Pengaruh Pengalaman Kerja, Independensi, Obyektifitas, Integritas, dan kompetensi terhadap Kualitas Hasil Pemeriksaan. Paper. Simposium Nasional Akuntansi (SNA) XII. IAI. Palembang.

Widiarta. (2013). Pengaruh Gender, Umur Dan Kompleksitas Tugas Auditor Pada Kualitas Audit Kantor Akuntan Publik di Bali. E-Jurnal Akuntansi. 3(1), 109-118.

Wirosari, T.R., \& Fanani, Z. (2017). Pengaruh Umur, Gender, dan Pendidikan terhadap Perilaku Risiko Auditor dalam Konteks Audit atas Laporan Keuangan. Jurnal Ekonomi dan Bisnis Airlangga (JEBA)| Journal of Economics and Business Airlangga. 27(1). 


\section{APPENDIX}

Appendix 1. List of entities and 2016 audit reports

\begin{tabular}{|c|c|c|c|}
\hline No. & Entity & Total & Audit Reports \\
\hline \multirow[t]{4}{*}{1} & Jambi Province & 1 & $\begin{array}{l}\text { Management and Accountability of Employee Expenditures and } \\
\text { Goods Expenditures for Year } 2016 \text { of Provincial Government in } \\
\text { Jambi }\end{array}$ \\
\hline & & 1 & $\begin{array}{l}\text { Management and Accountability of Capital Expenditures Year } \\
2016 \text { of Provincial Government in Jambi }\end{array}$ \\
\hline & & 1 & $\begin{array}{l}\text { Management of Local Government Governance Effectiveness in } \\
\text { Fostering BUMD (Regional-Owned Business Entities) Year } \\
\text { 2011-2016 of Provincial Government in Jambi }\end{array}$ \\
\hline & & 1 & $\begin{array}{l}\text { Effectiveness of Local Government Governance in Regional } \\
\text { Development Planning and Budgeting for 2014-2016 of } \\
\text { Provincial Government in Jambi }\end{array}$ \\
\hline \multirow[t]{2}{*}{2} & $\begin{array}{l}\text { Batang Hari } \\
\text { Regency }\end{array}$ & 1 & $\begin{array}{l}\text { Management and Accountability of Employee Expenditures and } \\
\text { Goods Expenditures for Year } 2016 \text { of Batang Hari Regency } \\
\text { Government in Muara Bulian }\end{array}$ \\
\hline & & 1 & $\begin{array}{l}\text { Management of Local Government Governance Effectiveness in } \\
\text { Fostering BUMD (Regional-Owned Business Entities) Year } \\
\text { 2011-2016 of Batang Hari Regency Government in Muara Bulian }\end{array}$ \\
\hline \multirow[t]{2}{*}{3} & Bungo Regency & 1 & $\begin{array}{l}\text { Management of Regional Assets for } 2015 \text { and Semester I of } 2016 \\
\text { of Bungo Regency Government in Muara Bungo (SPI) }\end{array}$ \\
\hline & & 1 & $\begin{array}{l}\text { Management and Accountability of Employee Expenditures and } \\
\text { Goods Expenditures for Year } 2016 \text { of Bungo Regency } \\
\text { Government in Muaro Bungo }\end{array}$ \\
\hline \multirow[t]{2}{*}{4} & $\begin{array}{l}\text { Merangin } \\
\text { Regency }\end{array}$ & 1 & $\begin{array}{l}\text { Management and Accountability of Regional Expenditures for } \\
2016 \text { of Merangin Regency Government in Bangko }\end{array}$ \\
\hline & & 1 & $\begin{array}{l}\text { Effectiveness of Local Government Governance in Regional } \\
\text { Development Planning and Budgeting for 2014-2016 of } \\
\text { Merangin Regency Government in Bangko }\end{array}$ \\
\hline 5 & $\begin{array}{l}\text { Sarolangun } \\
\text { Regency }\end{array}$ & 1 & $\begin{array}{l}\text { Management and Accountability of Regional Expenditures for } \\
2016 \text { of Sarolangun Regency Government in Sarolangun }\end{array}$ \\
\hline \multirow[t]{2}{*}{6} & $\begin{array}{l}\text { Tanjung Jabung } \\
\text { Barat Regency }\end{array}$ & 1 & $\begin{array}{l}\text { Management of Regional Assets for } 2015 \text { and Semester I of } 2016 \\
\text { of Tanjung Jabung Barat Regency Government in Kuala Tungkal }\end{array}$ \\
\hline & & 1 & $\begin{array}{l}\text { Effectiveness of Local Government Governance in Regional } \\
\text { Development Planning and Budgeting for 2014-2016 of Tanjung } \\
\text { Jabung Barat Regency Government in Kuala Tungkal }\end{array}$ \\
\hline 7 & $\begin{array}{l}\text { Tanjung Jabung } \\
\text { Timur Regency }\end{array}$ & 1 & $\begin{array}{l}\text { Management of Regional Assets for } 2015 \text { and Semester I of } 2016 \\
\text { of Tanjung Jabung Timur Regency Government in Muara Sabak }\end{array}$ \\
\hline \multirow[t]{2}{*}{8} & Jambi City & 1 & $\begin{array}{l}\text { Management of Inpatient Care at H. Abdul Manap Hospital in } \\
\text { Jambi City in 2013-2016 in Jambi }\end{array}$ \\
\hline & & 1 & $\begin{array}{l}\text { Management of Local Government Governance Effectiveness in } \\
\text { Fostering BUMD (Regional-Owned Business Entities) Year } \\
\text { 2011-2016 of Jambi City Government in Jambi }\end{array}$ \\
\hline \multirow[t]{2}{*}{9} & $\begin{array}{l}\text { Sungai Penuh } \\
\text { City }\end{array}$ & 1 & $\begin{array}{l}\text { Regional Revenue for } 2015 \text { and Semester I of } 2016 \text { of Sungai } \\
\text { Penuh City Government in Sungai Penuh }\end{array}$ \\
\hline & Total & 17 & \\
\hline
\end{tabular}


Appendix 2. list of entities and 2017 audit reports

\begin{tabular}{|c|c|c|c|}
\hline No. & Entity & Total & Audit Reports \\
\hline 1 & Jambi Province & 1 & $\begin{array}{l}\text { Special Purpose Audit for the Management and } \\
\text { Accountability of Regional Expenditures of } 2017 \text { of } \\
\text { Jambi Province Government in Jambi }\end{array}$ \\
\hline \multirow[t]{2}{*}{2} & Batang Hari Regency & 1 & $\begin{array}{l}\text { Performance of the Implementation of Population } \\
\text { Administration in Batang Hari Regency Government and } \\
\text { Other Related Agencies of } 2015 \text { to Semester I of } 2017 \text { in } \\
\text { Muara Bulian }\end{array}$ \\
\hline & & 1 & $\begin{array}{l}\text { Special Purpose Audit (DTT) for Management and } \\
\text { Accountability of Regional Expenditure of } 2017 \text { for } \\
\text { Batang Hari Regency Government in Muara Bulian }\end{array}$ \\
\hline 3 & Bungo Regency & 1 & $\begin{array}{l}\text { Performance of the Implementation of Population } \\
\text { Administration in Bungo Regency Government and } \\
\text { Other Related Agencies of } 2015 \text { to Semester I of } 2017 \text { in } \\
\text { Muara Bungo }\end{array}$ \\
\hline 4 & Kerinci Regency & 1 & $\begin{array}{l}\text { Performance for Fulfilling the Needs of Professional } \\
\text { Teachers and Education Personnel of FY } 2015 \text { to } \\
\text { Semester I of } 2017 \text { in Kerinci Regency Government }\end{array}$ \\
\hline 5 & Merangin Regency & 1 & $\begin{array}{l}\text { Special Purpose Audit (DTT) for Management and } \\
\text { Accountability of Regional Expenditure of } 2017 \text { for } \\
\text { Merangin Regency Government in Bangko }\end{array}$ \\
\hline 6 & $\begin{array}{l}\text { Muaro Jambi } \\
\text { Regency }\end{array}$ & 1 & $\begin{array}{l}\text { Performance of the Implementation of Population } \\
\text { Administration of FY } 2015 \text { to Semester I of } 2017 \text { of } \\
\text { Muaro Jambi Regency Government in Sengeti }\end{array}$ \\
\hline 7 & $\begin{array}{l}\text { Tanjung Jabung Barat } \\
\text { Regency }\end{array}$ & 1 & $\begin{array}{l}\text { Performance of Management of Drugs in the } \\
\text { Implementation of National Health Insurance of Year } \\
2016 \text { and Semester I of } 2017 \text { of the Tanjung Jabung } \\
\text { Barat Regency Health Office, FKTP, Regional Public } \\
\text { Hospital (RSUD) K.H Daud Arif And Other Related } \\
\text { Agencies }\end{array}$ \\
\hline 8 & Tebo Regency & 1 & $\begin{array}{l}\text { Special Purpose Audit (DTT) for the Management and } \\
\text { Accountability of Regional Expenditures of FY } 2017 \text { of } \\
\text { Tebo Regency Government in Muara Tebo }\end{array}$ \\
\hline 9 & Sarolangun Regency & 1 & $\begin{array}{l}\text { Special Purpose Audit (DTT) for the Management and } \\
\text { Accountability of Regional Expenditures of FY } 2017 \text { of } \\
\text { Sarolangun Regency Government in Sarolangun }\end{array}$ \\
\hline 10 & Jambi City & 1 & $\begin{array}{l}\text { Special Purpose Audit (DTT) for the Management and } \\
\text { Accountability of Regional Expenditures of FY } 2017 \text { of } \\
\text { Jambi City Government in Jambi }\end{array}$ \\
\hline 11 & PDAM Tirta Mayang & 1 & $\begin{array}{l}\text { Performance of Regional Water Supply Company } \\
\text { (Perusahaan Daerah Air Minum/PDAM) Tirta Mayang } \\
\text { of FY } 2016 \text { and Semester I of } 2017 \text { in Jambi }\end{array}$ \\
\hline
\end{tabular}

Source: IHPS I Year 2017 Audit Board of the Republic of Indonesia 